\title{
Obstacles of Research in Islamic Economics
}

\author{
Mohammad Nejatullah Siddiqi
}

mnsiddiqi@hotmail.com

\begin{abstract}
This paper concentrates on six obstacles that hinder the advancement of research in Islamic Economics (IE). These are: the absence of historical studies, the lack of empirical studies, the insufficient institutional support, the non-adherence to ethical norms of research and publication, the weakness in vision. Failure to distinguish between the divine and the human in the Islamic heritage The paper discusses in details these obstacles and proposes an action agenda for the remedy. In what follows we discuss each one of these, with the existing Islamic economics literature in mind. We then suggest possible ways of removing these obstacles to further progress in Islamic economics research. wa billah al-tawfiq.
\end{abstract}

\section{Introduction}

Before we launch our enquiry it is appropriate to ask ourselves the question: Why are we doing it? All is not well with Islamic economic research. The enthusiasm of the early decades has gone. The surge in enrolment in Islamic economics courses, especially at the post- graduate level, observed during the eighties of the last century, has all but subsided. In its place we have kids looking for appropriate qualifications in "Islamic Finance", and sprouting of institutions offering such courses "on line," to meet the growing needs of the 'industry'. Nothing bad. No regrets. The question is, what about the grand idea of providing an alternative to capitalism and socialism, that is informed by moral purpose and inspired by an spiritual vision. Has it yielded to a desire to join the flock at its own terms? I suspect it is so, and that this is rooted, among other things, in the change of times. In the sixties and seventies of twentieth century the world of Islam was abuzz with all things Islamic: education, society and state. Currently, in the first decade of the twenty-first century, there is a collapse of grand agendas leaving a pathetic scenario in which everything is in a 
flux: education, society, state. As I proceed to discus the micro-causes of decline in Islamic economic research, I beseech you not to lose sight of the macro- framework in which the future would unfold itself. The grand Islamic agenda has been pushed back due to its own shortcomings.

\section{Lack of a Sense of History}

Islamic economics, insofar as its normative aspect is concerned, is based on divine guidance revealed in the seventh century Arabia to a desert people who later carried it to the fertile valleys in the north, west and east, and then across the mountains and beyond the oceans. People of all hues and colors, speaking different languages, and cherishing different traditions rooted in each people's unique past, tried to live that guidance. Trying to do the same in the twenty-first century in a globalising world, we need to know everything about these trials before we can draw a plan of action.

That is where we failed. The source of most of the economics projected as Islamic has been fiqh, which is largely based on the historical experiences of the first four centuries, mostly in what we now call the Middle East. Historical experiences over the next thousand years, especially those in Andalus, the Maghreb, India, South-East Asia, Turkey and Iran have neither been studied properly nor allowed full impact on figh. Among the very few attempts to sift through Islamic history for knowing more about such institutions and practices as waqf, zakat, mudaraba, suftajah, and such concepts as israf, infaq, etc. ${ }^{(1)}$, the sources covered are all in Arabic and from one particular region. This has deprived us of the variety of interpretation and diversity of experience in living according to Quran and Sunnah. Economic history of Muslim peoples is a very thinly researched area, and so is the economic thought of Muslims. This can hardly do, as living according to norms and concepts handed down centuries ago, is a challenging task, especially in economic affairs. It would be some help to know how Muslims responded to technological changes, expanding markets and new sources of energy over the centuries. As it stands, most of Islamic economic literature treated Islamic norms and concepts relevant for man's economic life to be above time and place, unaffected by increasing populations, urbanization, rising incomes, increasing trade and commerce, innovative ways of handling money and foreign exchange and faster means of transport and communication. That is unacceptable as even during the first few centuries of Islam, which did not witness any revolutionary change in sources of energy or technology, we have some variety of interpretation and diversity of practice. What we need is a closer look at what was going on in different regions at

(1) al-Faharis al-Tahliliyah lil-Iqtisad al-Islami (1985-86), 5 vols. Amman, Jordan, Maktabah Saleh Kamil \& al- Majma'al-Malaki li-Buhus al-Hasarah al-Islamiyah, Mussasaah Aal-al-Bayt. 
different times. That requires sifting through all available historical records, supplementing these by a study of stories (qisas), poetry and travelogues, court records, etc. This has to be done for all regions under Muslims, covering all the languages spoken by them.

Let us have it straight, history, even of Muslim peoples, is not a source of guidance for us. Divine guidance inheres only in Quran and Sunnanh of the Prophet, peace be upon him. We invoke history for the purpose Quran has recommended it to us: as $i b a r^{(2)}$. There are lessons to be learnt, warnings to be heeded. We run a great risk in ignoring history. Knowledge of history may save us from repeating mistakes and encourage us onto following into footsteps of those who succeeded.

A greater risk inheres in focusing on only part of Islamic history and ignoring the rest. This elevates a particular history to a status it cannot claim and does not deserve. By committing this mistake we run the risk of alienating parts of humanity for no fault of theirs.'

\section{Being Realistic: Feel of the Ground under your Feet}

We know very little about contemporary Muslim economic behavior. There is a lot of work on what Muslims should be doing as consumers, producers, employers, traders and managers. But what they actually do, and whether it is any different from what others are doing in similar situations, we hardly ever investigated. The same applies to our distinctive institutions like awqaf, zakat funds, even Islamic financial institutions. The question: What to do if and when a Muslim behaves differently from the way he or she should behave, cannot be addressed without knowing what actual Muslim behavior is. Similarly we need to know whether our institutions are actually playing the role claimed for them in Islamic economic literature. Lack of adequate attention to finding out the actual state of Muslim individuals and institutions, needs some explanation. It will be too much to assume that we do not care, that all we care about is announcing what the desired model is. This cannot be true as the whole thing about Islamic economics is an offshoot of the movement towards Islamic living that the second and third decades of the last century witnessed. In other words Islamic Economics is not an academic exercise (no economics ever was). It is an offshoot of the Islamic Movement. So it must be caring about change, change from the current behavior and institutional structures to those in accordance with Islamic norms. But can we do so without first knowing what the state of Muslim individual and of Muslim institutions is, and why?

(2) Certainly in the stories of the bygone people there is a lesson for people of understanding [12:111.] Also see, 59:2; 3:12. 
We claim a Muslim would behave ethically. That there are higher spiritual horizons he or she is looking at in the conduct of business. But how far they do so, and what explains the discrepancy? Does the fault always lie with human perfidy? Or, someone may have overshot in defining the norms and developing the concepts. There is also the problem that inheres in comparing today's Muslims with the idealized image of Muslims during the days of the Prophet and the caliphs. The present we know and observe, but the past is partly a mental construct. The reports that form the basis for that construction are neither exhaustive nor all authentic. But their romantic spell is capable of clouding judgment and suppressing rational evaluation.

I suspect that may have happened, especially with regard to the period immediately following the Prophet. It might have been found to be prudent to underplay departures from Islamic norms as perceived. But that dilutes the didactic value of history as honest recording of facts.

A final verdict must await fresh research. Meanwhile it will do no harm to know the current state of affairs thoroughly. That needs being done with regard to individual behavior in all aspects relevant to economics. It needs being done for all regions and ethnic groups in matters where geography may matter. For comparison we need studies of non-Muslim behavior too, as we want to know the impact of Islam, if any. The same has to be done about institutions like family, bazaar, and inter-Islamic trade as well as uniquely Muslim institutions like inheritance, the Hajj, waqf and zakat.

If there is one lesson to be learnt from the collapse of the socialist agenda and demise of Soviet Russia during the short span of less than a century, it is that one must feel the ground underneath one's feet before launching on a grand march to the ideal. Before one dreams of successes to come, there may be lessons to learn from current failures. This is especially true of priorities. What is to be done in case the peoples' own concerns are widely different from priorities in the agenda of the reformers? Shall the reformers readjust to ground realities or persist with their own sequencing?

Consider the current focus of Islamic economists on Islamic finance and dearth of Islamic economic literature on poverty removal, inequality and development. Among the billion plus Muslims of the world, how many are bothered about banking and finance? How many of the over six billions inhabiting the planet, considering the fact that Islamic economics is for all? 


\section{Research Needs Money}

Modern research needs lots of resources. Whether it is historical studies of the kind indicated above or empirical studies of the type we were talking about in the previous paragraphs, they both require large teams making sustained efforts over long periods of time. Their findings have no industrial application, so the market is not going to finance them. The costs of these public goods have to be borne by the Muslim society. If the record of the last forty years is an indicator (in which very few Muslim governments assigned any resources for these tasks, and the assignments have been too meager to deserve any mention), Muslim governments would not be funding the type of fundamental researches outlined above. Most of the contemporary regimes in the Islamic world that have resources to spare are happy with the status quo. Whatever the perceived tension between that status quo and the popular construct of Islamic history, it is well contained and poses no threat to the status quo. But the same cannot be true about the outcome of new probes into the past with a new set of questions in mind.

Most of the research output in Islamic economics so far owes itself to private charity and/or dedication of the researchers themselves. Happily the financial resources of the private sector are destined to grow with the passage of time. More and more wealth is likely to be created by human ingenuity and the relative share of scarce resources such as petroleum is destined to decline. While one should continue pressurizing governments, especially those in democratic countries, for allocating funds for historical and empirical research, current hope lies in persuading the voluntary sector to change its priorities from doing more of the same to exploring new directions. One ground for persuasion is the failure of the old to inspire fresh positive thinking and produce new agenda for reconstruction of the ummah. As things stand now, all new energy seems to be destined for destroying what is perceived to be un-Islamic, with no clear vision of what to replace it with. It is precisely for recovering such a vision that fresh fundamental research in the past and a new understanding of the present is needed. Those who care for the destiny of the ummah and that of humanity, and there are many, would be willing to open their purses without expecting any material returns to themselves. The important thing is to impress on our people that the stakes are very high. Unless the ummah is given a new direction that is credibly rooted in the past, convincingly realistic regarding the present and reasonably confident about building a better future, an avalanche of crises may sweep away many a promising career.

Resources, to the extent available, need to be spent judiciously. It is not advisable to house all research under one roof or in one country, even in one region. It must also be multi lingual. Universities, autonomous institutes and associations like the International Association for Islamic Economics should all 
partake in this enterprise. A role awaits the publishing industry too, by way of patronizing young scholars and providing them with initial impetus. No less important is need for the media, including the mimbar, to orchestrate the new priorities so they are accepted by the ummah as a whole.

\section{Rights Protection}

Plagiarism is an endemic disease afflicting scholarship. But does it pose a threat to proper development of Islamic economic scholarship? Frankly speaking, I don't know. There are indicators, however that it is assuming bothersome proportions. There have been complaints on ibf net, the popular Islamic economic discussion forum in English. Some senior teachers and authors have also told me the same about research and publications in the Arabic language.

It will take time and efforts to root out the evil. Teachers and publishers have special responsibility, but peer review and vigilance must also play its role more effectively. But will they? We have some notions about knowledge being for the benefit of all, any proprietary claims to new ideas being essentially bad, un-Islamic. Besides being baseless in law and morality, such notions totally ignore the way new facts are discovered, fresh ideas originate, and new knowledge germinates and flourishes in a society. Original research in modern times demands life-long dedication. Each small brick laid could be the basis on which further edifice may rest. Unless it is secured in the name of the originator, and brings him or her any recognition and/or rewards society thinks fit for awarding, there would be no incentive for follow up work. It is in society's interest to protect the rights of researchers, authors and publishers from plagiarism and piracy so that the flow of scientific research continues unabated. This social protection does not depend on law alone. More than legal provisions, it needs, first of all, to be clearly recognized as the norm. No one, neither a student nor an author has a right to lift even a sentence or two from any author's work and present it as his or her own, without reference to the source and proper acknowledgement.

Cheating in scholarship is worse than robbing someone of material possessions. Plagiarism, unlike robbery, harms society much more than it hurts the victim. Taking it lightly is like allowing quakes to wear the mantle of physicians. The intellectual health of a society that fails to prevent it will be at grave risk.

\section{The Essential and the Peripheral}

Islam is for all times and all places, and so are its teachings that are relevant for the economic life of man. It was, however, revealed in the seventh century 
Arabia. The time and place in which the Prophet, peace be upon him, gave Islam's first concrete exemplification was bound to have its stamp on that example. But what was local and specific to those times cannot form part of the universal and eternal Islam. We who are engaged in living Islamically in the twenty-first century in a globalising world have the responsibility of sifting the eternal and the universal for implementation now and here, implementation that is bound to bear the stamp of a changed locale in a changed time. While all Muslims share this responsibility, and have to partake in its discharge, each according to his or her capacity, Muslim economists and social scientists have special responsibility. Having a better understanding of the changes that have occurred since the early centuries of Islam, and the features that distinguish modern living conditions from living in those times, they can identify the eternal and the universal, fit for adaptation and implementation.

The record of Islamic economic research so far has not been very promising. Islamic economists hardly did any better than those without any learning of social dynamics, specializing only in traditional Islamic sciences developed more than a thousand years ago. Hopes of getting better results by bringing the two expertise together by housing them in the same institution and/or seating them around the same conference table have not been very encouraging ${ }^{(3)}$. The result is a kind of intellectual paralysis. What is worse is the exploitation of this situation by a section of the market to offer conventional goods in superficial Islamic wrappings in the name of Islam.

It will take going into very many details fully to substantiate the above. I do not think it is necessary, even proper, to attempt doing that in this paper. I wish the task of substantiating (or refuting!) is taken up by someone with more time and energy than available to this writer. But I cannot miss this opportunity of giving at least one example, that of insurance. The Islamic economic literature on insurance during the last half- century, and the corresponding practice in the name of Takaful and Islamic insurance, exemplifies the problem, the predicament and the dangers I have indicated in the previous paragraph ${ }^{(4)}$.

In a world in which even such problems created by rapid technological change as job insecurity and increasing inequality in the distribution of income,

(3) Mohammad Nejatullah Siddiqi, 'Shariah, Economics and the Progress of Islamic Finance: The Role of Shariah Experts", Seventh Harvard Forum on Islamic Finance, 21 April, 2006. Available at the author's website: www.siddiqi.com/mns.

(4) Isa Abduh (1978) al-Tamin bayn al-Hill wa'l Tahrim, Cairo, Dar al-I'tisam. The book also records views of more than a dozen scholars other than Dr. Issa Abdoh. For the current position, Mohammed Obaidullah (2005) Islamic Financial Services, Jeddah, King Abdulaziz University, pp: 119-141. 
are sought to be tackled by insurance ${ }^{(5)}$, we are still discussing whether the idea of insurance itself is valid. Scholars would generally regard as alien, and therefore unacceptable, the idea of random events being subject to regularities that could be discovered, given a mathematical formulation and used for insuring against risk. Yet the same scholars would easily accept the fiction of tabarru' (donation) to validate thinly wrapped conventional insurance ${ }^{(6)}$.

I do not want to debunk the various Islamic insurance products available in the market. Let a hundred flowers bloom. What I am lamenting is a failure to accept anything that does not fit in the old mould despite its obvious wisdom. In trying to abide by derived rules we have distanced ourselves from the very source of rules. We have already noted the anomaly of Islamic economic research relegating poverty removal to the backburner and bringing investing rich peoples' surpluses for making them richer to the fore. That is how essence is overwhelmed by the peripheral.

The remedy lies in focusing on the vision of a Muslim and that of an Islamic society before we attend to rules of conduct and ways and means for their implementation. The so-called economic rules of individual conduct and social policy, most of them lifted from secondary sources, blur our vision of the total picture because we are living in a different time and place. The better method is to perceive and conceptualize the totality from out of the primary sources, the Quran and the Sunnah. All the rest should follow and not lead, insofar as Islamic economic research is concerned.

\section{The Human Element in the Islamic Heritage}

This brings me to the last point: The need to distinguish what is human from what is divine in our Islamic heritage. The Prophet, peace be upon him, brought the word of God and explained it by living it and guiding a whole generation of men and women organize their lives, including their economic affairs, in accordance with divine guidance. The word of God is preserved in its originality, un-adulterated by word of man. But the same is not true of anything else. As the Prophet leaves the scene and his companions are left to fend for themselves, the problem gets more complicated. It is no longer a matter merely

(5) Robert J . Shiller (2003) The New financial Order, Risk in the 21st Century, Princeton University Press, : 4-7 \& 149-164.

(6) One scholar is reported to have defined it as " ..a contract of donation with a condition of compensation...". See the site http://www.kantakji.org/fiqh/files/insurance/diffbwconvIns.pdf (accessed 21 March 2007) More on reciprocal tabarru'

http://www.Islamic-world.net/economics/takaful_intro.htm, Many other details are available at websites of Bank Negara Malaysia and other Malaysian Islamic Financial Institutions and on IBF NET. 
of authenticity of reports. We are now dealing with men like us, without any direct link with divinity. Facing new challenges, they no longer had the Prophet to ask how to meet them. All they had is the Quran and what they had heard from the Prophet or, seen him doing in different situations. Building on that, they had to decide for themselves, and they did. Times moved on. The second and third centuries of Islam brought new challenges and explored new solutions. It is during these times that most of the recorded Islamic heritage took shape. Besides the vast literature on what is characterized as Islamic sciences the age produced a rich harvest of living traditions, arts and culture. Supplemented by the intellectual contributions in the following centuries, that is the heritage we cherish and seek inspiration from in our own enterprise of living an Islamic life in this globalized world of the twenty-first century. So far so good.

In exercising ones own judgment in the enterprise of Islamic living, it is good to have so much to fall back on. It is a great help. But one should not be constrained by the sayings and doings of other humans. The divine is binding but the human is not. Additional constraints thwart fresh thinking and innovation. Sacralization of the non-sacred has been a great source of degeneration in human history. It is one thing to treat history as help and inspiration. It is very different when we try to recreate it in a changed world, and that too in economic affairs. History, even Islamic history, is not sacred. We run a great risk by giving it that status.

Well said, but has it any relevance to the subject in hand? I think it has. You need only a cursory glance at the Islamic economic literature on taxation, fiscal policy, social welfare and development financing to conclude that the writer is focused on some script, rarely looking up to gauge the reality faced in modern living. Most writers on Islamic Public Finance ${ }^{(7)}$ are writing history, telling us how to recreate it. The divine in our heritage does not offer such script, so, how come? That is the problem.

The problem is not confined to archaic treatment of novel modern situations and issues. Our fixation with a particular history not only alienates us from current reality, it also isolates us from the rest of humanity. It reinforces Muslims' sense of being different from others to undue proportions, making frank, sincere outreaching and interaction almost impossible. The normal process of learning from others' experiences and contributions is replaced by, at the least, indifference and apathy, and often by suspicion and hostility. No wonder we get the same in response.

(7) S.A. Siddiqi $(1948,1975)$ Public Finance in Islam, Lahore, Sheikh Mohammad Ashraf; Ibrahim Yusuf Ibrahim (1980) al-Nafaqat al-Ámmah fi'l-Islam, Cairo, Matabi' Diyab; ... (1989-90) al-Idarah al-Maliyah fi'l-Islam, vol 3; s. Amman, Mu'assasat Aal al-Bayt. 
This situation has to be rectified before it goes out of hand. There is no better area for making a beginning than economics. I say this because the need to focus on the divine in human heritage and treat the human only as efforts in implementation from which lessons can be drawn is most obvious in economic matters. It is the economic affairs of man that bear the brunt of technological change and are often harbingers of change in other aspects of life. It is in economics more than in other areas that our focus should be on Maqasid alShri $a h^{(8)}$ (the objectives of Islamic Law) rather than what is commonly perceived as Law. Islamic economic research, unbound from the chains that human elements in Islamic heritage have put around it, can then bring Muslim intellectuals out of their shell into the company of other intellectuals for exploring ways and means of delivering humanity from the unprecedented predicament it finds itself in.

\section{Regaining Self Confidence}

A shrinking from independent thinking and total reliance on Islamic heritage came to Muslims after the first five hundred years of their history gradually and due to many factors. First it was to save Islamic law from becoming a hand-maid of petty rulers in a world of Islam torn asunder by sectarian squabbles and internecine wars. Then came the colonial era and the onslaught of Christian missionaries in the wake of Western armies. The new emperors produced their own courtiers from out of greedy elite among the natives. Islamic thought was defended from inroads by foreigners and tampering by motivated insiders by declaring it self-sufficient and immune to change. All that is history. Things have been changing after the coming of Muslim peoples from out of the yoke of colonialism during the last century. The intellectual scene of the ummah is humming with activity, the emergence of Islamic economics being one of its fruits. It takes time. There is no justification for despondency. But speed matters in this age of rapid change. The obstacles to progress in Islamic economic research are all removable. We can do that. Better begin by diverting existing resources to priority areas of research. The next step should be to revamp the existing institutions involved in Islamic economic research by giving them greater autonomy, making them more democratic and providing them with more resources. Let the newly rich among Muslims in India, China and South East Asia realize their potential and cast away the image of dependence on largesse from the oil-rich for funding their universities and research institutions. We need a strong center for research in Islamic economics located in the West. This will serve the dual purpose of benefiting from the

(8) Mohammad Nejatullah Siddiqi (2004) Key Note Address to Round Table on Islamic Economics, Jeddah IRTI, May 26-27, 2004. Available on the author's website: www.siddiqi.com $/ \mathrm{mns}$ 
well-established research traditions in the West and affording Western scholars interested in the area, and they are an increasing lot, a closer look at the ideas.

The toughest nut to crack are the two last mentioned obstacles, failure to prioritize so that the essence prevails over the form and detaching the human accretions from the eternal and universal divine guidance. Two sides of the same coin, they are so well entrenched in traditional Islamic scholarship that even their mention is bound to raise eyebrows. Yet there would be no breakthrough without removing these obstacles. They are borne of precautionary defensive mechanisms created during the last one thousand years to protect Islam from corruption by the un-scrupulous Muslim autocrats, foreigners and their lackeys. Even after two hundred years of Islamic revivalist movements, many calls to ijtihad and fresh thinking, and hundreds of conferences and seminars to revive creativity among Muslim intellectuals, fear of the unknown makes the commonality of Muslims and their mentors stay close to the beaten path, if not quite on it. We may err if we think independently. There is bound to be variety of opinion if free discussion and independent judgment is encouraged. Far-flung regions of the Islamic realm, now bound together by adherence to half a dozen major schools of fiqh, may opt for newer directions, especially in matters of economic policy. And so on and so forth, goes the long list of reasons advising prudence, conservatism, at the least wait and see. The net result is restraining the pious, the knowledgeable and those likely to evoke trust from the Muslim masses, leaving the field entirely, or mostly, to dare devil mujtahids. The outcome, not entirely unexpected, becomes yet another reason why the status quo should not be disturbed!

The status quo cannot sustain itself. If we do not change in a wellconsidered manner, change will be forced onto us in haphazard manner. I already see it happening in an area so dear to us: Islamic economists ${ }^{(9)}$, the area of Islamic finance. The remedy lies in getting rid of the fear psychosis, the fear of committing mistakes in matters of religion, thereby inviting the wrath of Allah. That is too dumb a view of God to be taken seriously. Did the Prophet not tell us there is a reward awaiting even the mujtahid who errs? ${ }^{(10)}$, We have faith in God that needs to be buttressed by confidence in ourselves. The chances

(9) Mohammad Nejatullah Siddiqi (2006) Islamic Banking and Finance in Theory and Practice: A Survey of State of the Art, in Islamic Economic Studies (Jeddah), Vol. 13, No. 2, pp: 1-48, Also by the same author (2007) Economics of Tawarruq: How its Mafasid overwhelm the Masalih, Harvard Law School and London School of Economics, Workshop on Tawarruq, Available at the author's website www.siddiqi.com $/ \mathrm{mns}$.

(10) Abu Dawood in his Sunnan has the following report: ...Amr Ibn al-Ás reports that the Prophet, peace be upon him, said, "When a ruler decides and exercises his judgment and gets it right, he is rewarded twice. When he exercises his judgment to decide and errs, he is rewarded once." Hadith \# 3574 . Kitab al-Aqdiyah, Bab \# 2. 
of making a mistake today are less, not more, than the chances of a Muslim thinker making a mistake in the third century of Islam. We have better access to Quran and Sunnah, more works on other Islamic sciences within easy reach, and better, faster means of mutual consultation and discussion than was available to our fore runners.

\section{To the Organizers of this Discussion}

I congratulate the organizers. At least you recognized there are obstacles to research in Islamic economics that need serious discussion. You felt more of the same would not do. We need to take newer directions, break new paths. I have contributed my humble bit. I am sure the panel discussion will throw up ideas we can pursue on to the road of progress.

\section{References}

Abdoh, Issa (1978) al-Tamin bain al-Hill wa-l Tahrim, Cairo, Dar al-I'tisam.

Al-Majma` al-Maliki (1985-86) al-Faharis al-Tahliliyah li'l-Iqtisad al-Islami, 5 vols. Amman, Jordan, Mu'assasah Aal-al-Bayt.

Ibrahim, Ibrahim Yusuf (1980) al-Nafaqat al-Ámmah fi'l Islam, Cairo, Matabi' Diyab; ... (1989-90) al-Idarah al-Maliyah fi'l Islam, 3 vols. Amman, Mu'assasat Aal al-Bayt.

Obaidullah, Mohammad (2005) Islamic Financial Services, Jeddah, King Abdulaziz University pp: 119-141.

Shiller, Robert J. (2003) The New financial Order, Risk in the $21^{\text {st }}$ Century, Princeton University Press, pp: 4-7 \& 149-164.

Siddiqi, Mohammad Nejatullah (2004) Key Note Address to Round Table on Islamic Economics, Jeddah IRTI, May 26-27, 2004. Available on the author's website: www.siddiqi.com/mns (2006), 'Shariah, Economics and the progress of Islamic Finance: The Role of Shariah Experts ", Seventh Harvard Forum on Islamic Finance,21 April 2006.. Available at the author's website: www.siddiqi.com/mns (2006), Islamic banking and Finance in Theory and Practice: A Survey of State of the Art, in Islamic Economic Studies(Jeddah) , 13(2): 1-48, Also by the same author (2007) Economics of Tawarruq: How its Mafasid overwhelm the Masalih, Harvard Law School and London School of Economics, Workshop on Tawarruq, Available at the author's website: www.siddiqi.com $/ \mathrm{mns}$

Siddiqui, S. A. (1948, 1975) Public Finance in Islam, Lahore, Sheikh Mohammad Ashraf. 


\section{معوقات البحث في الاقتصاد الإسلامي}

\section{محمد نجاةالله صديقي}

mnsiddiqi@hotmail.com

العستخلص. تركز هذه الورقة على ستة عو ائق رئيسة تعترض تقدم البحث في الاقتصاد الإسلامي، وهي: غياب الدراسات التاريخيــة الملائمة، وغياب الدر اسات التجريبية، وغياب الــدعم المؤستـسـي

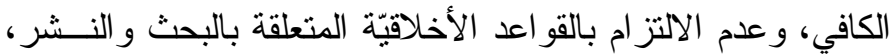

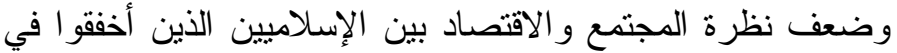
التمبيز بين ما هو أساسيّ وهامشيّ، و أخيرًا، الإخفاق في التمييـز

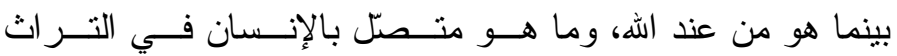
الإسلامي. وتتاقش الورقة كل عائق، آخذة في الاعتبــار أدبيّــات

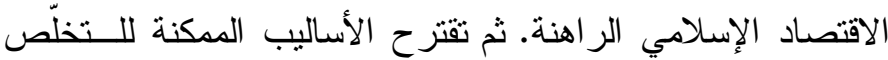
من هذه العو ائق لدعم تقدّم البحث في الاقتصاد الإسلامي. لإسمي. 